\title{
The Impact of Executive Coaching on Project Managers' Personal Competencies
}

\author{
Luis Ballesteros-Sánchez ${ }^{1}$, Isabel Ortiz-Marcos ${ }^{1}$, and Rocío Rodríguez-Rivero ${ }^{1}$
}

\begin{abstract}
Personal competencies have been shown to be increasingly reliable predictors of successful project managers. This research studies whether executive coaching is effective in strengthening personal competencies in the project management field. An experiment with 30 project managers and 30 observers has been conducted to determine, by means of a quantitative and qualitative approach, the impact of coaching on different competencies based on the Project Manager Competency Development Framework - Third Edition (Project Management Institute, 2017a). The conclusions reveal interesting insights, such as the finding that executive coaching has the greatest impact on behaviors related to leading, managing, and finding strategies for coping with challenging situations.
\end{abstract}

\section{Keywords}

executive coaching, personal competencies, project management, project manager

\section{Introduction}

The project manager is increasingly a key agent in the development of the business, growth, and capabilities of organizations, particularly in a changing, complex, and challenging environment (Project Management Institute [PMI], 2017a, 2017b). Challenges that project managers must address include leadership style issues, stress, uncertainty, motivation, learning, teamwork, and the development of a team culture (Berg \& Karlsen, 2013). The project manager's role is evolving and should be strengthened with a broad range of knowledge and skills that are complementary to the traditional functions of project administration in order to acquire other competencies that modern project management requires. This includes management and leadership competencies that contribute to the strategic needs of the organization (Ahsan \& Ho, 2013).

Competencies can be defined as clusters of knowledge, aptitudes, attitudes, and behaviors that are needed to accomplish a piece of work (Boyatzis, 1982). Similarly, Parry (1996) defines competencies as a set of related knowledge, skills, and personal characteristics that have an influence on individual and group work in an organization, are related to job performance, and can be improved by training and professional development.

The importance that is attributed to the strategic role of a project manager in organizations has led in recent decades to the growing development of frameworks of international competencies and professional standards for project management.
Some of the main competency frameworks are the Project Management Professional (PMP) ${ }^{\circledR}$ certification from the Project Management Institute (PMI, 2017b), the International Project Management Association certification (IPMA, 2015), the competency framework of the Association for Project Management (APM, 2008), and the professional standards that have been defined by the Australian Institute of Project Management (AIPM, 2008). These competency standards provide guidance to individuals and organizations for the definition, assessment, and development of project manager competencies. Their use has been extended internationally.

Until now, competency frameworks have developed and mapped both technical and personal competencies for project managers. However, the focus has been mainly on the assessment and development of knowledge and performance for the use of tools and techniques in project management rather than on personal competencies (Takey \& Carvalho, 2015). Nevertheless, the number of research studies and publications concerning personal competencies has grown recently (Brière,

\footnotetext{
' Universidad Politécnica de Madrid, Department of Organization Engineering, Business Administration and Statistics, Madrid, Spain
}

\section{Corresponding Author:}

Luis Ballesteros-Sánchez, Universidad Politécnica de Madrid, Department of Organization Engineering, Business Administration and Statistics. C/ José Gutiérrez Abascal 2, 28006 Madrid, Spain

Email: luisignacio.ballesteros@upm.es 
Proulx, Flores, \& Laporte, 2015; Chipulu, Neoh, Ojiako, \& Williams, 2013; Clarke, 2010a; Liikamaa, 2015; Meng \& Boyd, 2017; Müller \& Turner, 2010a; Skulmoski \& Hartman, 2010; Takey \& Carvalho, 2015).

Kerzner and Saladis (2011) undertook a study to learn why projects fail. They discovered that for many years the reasons were quantitative issues (planning, estimating, scheduling, or controlling), but in the modern period (from 1993 until the present), the importance of behavioral issues in order to achieve project success is emphasized. Ethical shortcomings, lack of employee engagement, low productivity, and weak relationships are considered to be the most critical issues. In keeping with this, other authors affirm that, when important projects fail, the investigation focuses on technical reasons, although the problem is often rooted in management failure (Sauser, Reilly, \& Shenhar, 2009). These analyses highlight the importance of the personal competencies linked to behavioral issues.

Context changes, such as an increase in project complexity, multicultural issues, and the growth of work by virtual teams, have led to a new era in which project managers' personal competencies are increasingly crucial to the achievement of project success (Azim, Gale, Lawlor-Wright, Kirkham, Khan, \& Alam, 2010; Chipulu et al., 2013). The demand for soft skills is even more pronounced in project management than in other business environments; as relationships must be developed more quickly and frequently, there are interpersonal interactions across organizational and professional cultures in a project environment (Druskat \& Druskat, 2006).

Personal competencies within the project management field have been defined as those behaviors, attitudes, and core personality characteristics that contribute to a person's ability to manage projects (PMI, 2017a). Personal competencies have been shown to be increasingly reliable predictors of successful project managers (Ahadzie, Proverbs, \& Olomolaiye, 2008; Boyatzis, 2008; Chipulu et al., 2013; Cheng, Dainty, \& Moore, 2005; Druskat \& Druskat, 2006; Stevenson \& Starkweather, 2010). While demands for successful project leaders continue to increase, it is important to better understand the key personal competencies of these professionals and how to strengthen them effectively (Azim et al., 2010; Ballesteros-Sánchez, Ortiz-Marcos, Rodríguez-Rivero, \& Juan-Ruiz, 2017; Creasy \& Anantatmula, 2013; Dippenaar \& Schaap, 2017; Obradovic, Jovanovic, Petrovic, Mihic, \& Mitrovic, 2013; Petter \& Randolph, 2009; Skulmoski \& Hartman, 2010).

The main methodologies identified for the development of competencies in project management are training (internal, external, group, individual, computerized, or on-the-job training), mentoring, and coaching (PMI, 2017a). For the development of personal competencies, executive coaching is gaining popularity. Executive coaching involves a series of one-on-one interventions between a professional coach and an executive (i.e., team leader to top management) with the purpose of enhancing the latter's behavioral change through selfawareness and learning, and ultimately contributing to individual and organizational success (Bozer, Sarros, \& Santora,
2014). Executive coaching provides a means of strengthening management and strategic capabilities and is also a key intervention for the development of organizations (Joo, Sushko, \& McLean, 2012). Nevertheless, empirical research that assesses the effects of coaching lags far behind the practice of coaching (Bono, Purvanova, Towler, \& Peterson, 2009; Dippenaar \& Schaap, 2017; Grant, Curtayne, \& Burton, 2009). The effectiveness of executive coaching needs to be clearly and scientifically demonstrated, providing experimental designs that include quantitative measures and comparable control groups (De Meuse, Dai, \& Lee, 2009; Page \& de Haan, 2014).

The goal of this research is to determine how project management coaching works with regard to its effectiveness in strengthening the personal competencies of project managers. An experiment with 30 active project managers has been conducted. The study included a group of 30 observers directly working with 15 project managers who participated in a coaching intervention, and a control group of 15 project managers who did not receive any intervention. The results of a qualitative and quantitative approach have been analyzed to determine the impact of coaching on different competencies. The conclusions reveal interesting insights, such as the fact that the greatest impact of executive coaching was on project managers' personal competencies related to leading and managing, as well as a high positive impact of coaching on finding strategies for coping with stress and difficult situations, such as conflicts and crises.

The next section provides an overview of relevant literature concerning project management personal competencies, which is followed by a review of executive coaching as a way to strengthen these competencies. The fourth section describes the research methodology. The fifth section provides the results, describing personal competencies that have been improved by the quantitative and qualitative approach. In the sixth section, we discuss the scientific implications of the research. The seventh section discusses the study's main limitations. The final section of the article provides a summary of main insights gained from the research.

\section{Project Management Personal Competencies}

Personal competencies connote the ability of a project manager to work effectively in a team and to build a cooperative effort within it (El-Sabaa, 2001). These skills primarily concern working with people, remaining sensitive to the needs and motivations of others in the team, and the ability to communicate (El-Sabaa, 2001).

A literature review of soft skills leads to the first theorists and authors on motivation (Blake \& Mouton, 1968; McGregor, 1967), who emphasized that an effective manager requires a set of personal competencies that are based on the consideration of human interactions, building trust, and showing empathy for other people (e.g., in problem solving). Effective managers must develop their own personal point of view of human activity (El-Sabaa, 2001; Katz, 1955) so that they will: (1) recognize the feelings and sentiments that they bring to a situation, 


\begin{tabular}{|c|c|c|c|}
\hline Reference & Personal Competencies & Project Field & $\begin{array}{l}\text { Performance } \\
\text { Criteria }\end{array}$ \\
\hline $\begin{array}{l}\text { PMBOK }^{\circledR} \text { Guide } \\
\text { (PMI, 20I7b) }\end{array}$ & $\begin{array}{l}\text { Leadership, team building, motivation, communication, influencing, } \\
\text { decision making, political and cultural awareness, negotiating, trust } \\
\text { building, conflict management, and coaching }\end{array}$ & Generic & Not defined \\
\hline PMCD framework (PMI, 20I7a) & $\begin{array}{l}\text { Communicating, leading, managing, cognitive ability, effectiveness, and } \\
\text { professionalism }\end{array}$ & Generic & 90 items \\
\hline $\begin{array}{l}\text { Individual Competence Baseline } \\
\quad 4.0 \\
\text { (IPMA, 20I5) }\end{array}$ & $\begin{array}{l}\text { Self reflection and self management, personal integrity and reliability, } \\
\text { personal communication, relationships and engagement, leadership, } \\
\text { teamwork, conflict and crisis, resourcefulness, negotiation, and results } \\
\text { orientation }\end{array}$ & Generic & 49 items \\
\hline $\begin{array}{l}\text { APM competence framework } \\
\text { (APM, 2008) }\end{array}$ & $\begin{array}{l}\text { Communication, teamwork, leadership, conflict management, } \\
\text { negotiating, human resource management, behavioral characteristics, } \\
\text { learning and development, and professionalism and ethics }\end{array}$ & Generic & 60 items \\
\hline $\begin{array}{l}\text { Thornberry and Weintraub } \\
\text { (1983) }\end{array}$ & $\begin{array}{l}\text { Oral communication, leadership, intellectual skills, stress management } \\
\text { skills, and management skills }\end{array}$ & High technology & Not defined \\
\hline El Sabaa (200I) & $\begin{array}{l}\text { Mobilizing, communicating, coping with situations, delegating authority, } \\
\text { political sensitivity, high self esteem, and enthusiasm }\end{array}$ & Generic & 7 items \\
\hline $\begin{array}{l}\text { Dainty, Cheng, and Moore } \\
\quad(2005)\end{array}$ & $\begin{array}{l}\text { Team building, leadership, decision making, mutuality and } \\
\text { approachability, honesty and integrity, communication, learning and } \\
\text { understanding, self efficacy, and external relations }\end{array}$ & Construction & 43 items \\
\hline Patanakul and Milosevic (2008) & $\begin{array}{l}\text { Problem solving ability, conflict management, organization and discipline, } \\
\text { responsibility, proactivity and ambition, maturity, and self control and } \\
\text { flexibility }\end{array}$ & $\begin{array}{l}\text { Multiple project } \\
\text { management }\end{array}$ & Not defined \\
\hline Muzio and Fisher (2009) & Behavioral, motivational, and emotional intelligence & Engineering & 81 items \\
\hline Creasy and Anantatmula (2013) & $\begin{array}{l}\text { Communication apprehension, innovativeness, self monitoring, conflict } \\
\text { management, change initiation, and Myers Briggs (MBTI)-personality } \\
\text { type. }\end{array}$ & Generic & Not defined \\
\hline Zhang, Zuo, and Zillante (20I3) & $\begin{array}{l}\text { Service orientation, empathy, organizational awareness, inspirational } \\
\text { leadership, teamwork and collaboration, conflict management, } \\
\text { influence, and change catalyst }\end{array}$ & Construction & 59 items \\
\hline Mesly (2015) & Control, transparency, trust, fairness, cooperativeness and commitment & $\begin{array}{l}\text { International with } \\
\text { physical distance }\end{array}$ & 83 items \\
\hline Brière et al. (2015) & $\begin{array}{l}\text { Adaptability, span of abilities, management skills, communication, } \\
\text { personal qualities, interpersonal skills, leadership, ethics, networking } \\
\text { and local knowledge, capacity building, and change management }\end{array}$ & $\begin{array}{l}\text { International } \\
\text { development }\end{array}$ & Not defined \\
\hline
\end{tabular}

(2) have an attitude toward their own experiences that will enable them to reevaluate and learn from them, (3) develop the ability to understand what others are trying to communicate by their actions and words (explicitly or implicitly), and (4) develop the ability to successfully communicate their ideas and attitudes to others. Personal competencies include the set of social and emotional competencies that underlie a person's characteristics leading to effective or superior performance (Boyatzis, 1982, 2008). In addition, personal competencies are revealed in face-to-face behaviors that people exhibit in their effort to achieve something useful (Honey, 1988). In the field of project management, personal competencies also have been related to negotiation, change management, and stakeholder management (Frame, 2002; Gustavsson \& Hallin, 2014).

Personal competencies have been directly linked and positively associated with emotional intelligence (Boyatzis, 2009). Emotional intelligence (EI) is the "ability to monitor onés own and otheŕs feelings and emotions, to discriminate among them and to use this information to guide one's thinking and actions"
(Salovey \& Mayer, 1990, p. 189). The study and importance of emotional intelligence have been given consideration in the project management literature (Adams \& Anantatmula, 2010; Clarke, 2010a, 2010b; Creasy \& Anantatmula, 2013; Druskat \& Druskat, 2006; Geoghegan \& Dulewicz, 2008; Othman, Abdullah, \& Ahmad, 2009; Müller \& Turner, 2007, 2010a, 2010b; Obradovic et al., 2013; Shao, 2018).

Commonly, an effort has been made to break down and group personal competencies into the subset of dimensions that underlie them. This effort has been carried out by the main professional project management associations and by research that is oriented to the study of project management competencies.

A review of the relevant literature of project managers' personal competencies is provided in Table 1 to explain the dimensions of these kinds of competencies as an aid in selecting an appropriate systematic framework for this research and to better identify the main impacts of executive coaching by a quantitative and qualitative approach. 
The criteria that were used to select an appropriate personal competency framework for the research objectives were: (1) the framework needs to be applied to different project fields (generic); (2) it should be an extended and accepted international standard that provides descriptions of specific performance criteria; and (3) it must cover a sufficient number of items to be both comprehensive and relatively easy to apply for the personal measurement of project managers' competencies.

According to these criteria, the Project Manager Competency Development (PMCD) framework (PMI, 2007, 2017a) was selected as the main baseline to use to assess the impact of executive coaching on personal competencies. Nevertheless, all frameworks that were presented previously will help in the gathering of qualitative information in semi-structured interviews after the coaching interventions.

The PMCD framework (PMI, 2007, 2017a) uses an adequate number of performance criteria (90 items) that are valid for assessing a wide range of personal competencies that a competent project manager should use when working in any project context. With a hierarchical structure, this framework enables the comparison of six different competency units: communicating, leading, managing, cognitive ability, effectiveness, and professionalism. Also, many of the performance criteria of the personal competencies that are included in this framework cover similar factors to those within emotional intelligence. These include self-control, achievement orientation, positive attitude, organizational awareness, mentoring, influence, conflict management, and teamwork (Boyatzis \& Goleman, 1996).

On the other hand, the authors perceive some weaknesses in this framework that concern how certain performance criteria descriptions are presented. These can lead to misunderstandings or mixing of different concepts. Furthermore, although some specific competencies, such as conflict management and negotiating skills, are identified within the PMCD framework, they could be addressed more effectively.

With the combination of a quantitative and qualitative approach, this research takes advantage of PMCD strengths and complements the analysis by gathering information from semi-structured interviews after the coaching interventions.

\section{Executive Coaching to Strengthen Personal Competencies}

The increasing popularity and availability of coaching are improving project management practices, as coaching offers a real option to meet the development needs in a multitude of organizations. Coaching is increasingly used and includes practices in management consulting for the team, interpersonal skills, and leadership improvements (Rezania \& Lingham, 2009). It is a tool that improves long-term solutions by changing habits, attitudes, and work practices, taking care of the human aspects through an integrative and holistic approach. In addition, as a leadership tool, it has the added value of working in specific project environments and focusing on the action (Berg \& Karlsen, 2013).

Coaching is a professional relationship between a coach and a coachee in which the coach, by the use of powerful questions and active listening, addresses issues and challenges and helps the coachee to develop and change mental, behavioral, emotional, and learning patterns. This empowers the coachee to achieve important personal and professional goals. Coaching requires time in the current period but is an investment for the future that promises less stress, more self-confidence, and better interpersonal relations, with fewer conflicts and, therefore, greater efficiency (Berg \& Karlsen, 2013).

The overall effectiveness of executive coaching has been reported in a meta-analysis (Theeboom, Beersma, \& van Vianen, 2014), which found that executive coaching has a moderate and positive impact on individual performance and skills, wellness, self-improvement, work attitude, and goal-oriented self-regulation.

Coaching is presented by some authors as an effective intervention in organizations (Grant et al., 2009; Hall, Otazo, \& Hollenbeck, 1999; Jones, Woods, \& Guillaume, 2014; Olivero, Bane, \& Kopelman, 1997; Page \& de Haan, 2014; Smither, London, Flautt, Vargas, \& Kucine, 2003). Several researchers note the need for empirical knowledge about executive coaching and its application to organizational excellence, exploring what really does work and what does not, beyond conjectures or assumptions based on individual experiences (Berg \& Karlsen, 2007, 2013; Bono et al., 2009; De Meuse et al., 2009; Dippenaar \& Schaap, 2017; Grant et al., 2009; Page \& de Haan, 2014). This will be the only way to better understand the benefits of coaching and its utility as a tool for the improvement of management practices.

Unfortunately, less research has been developed to understand fully how coaching can be applied or its effectiveness in the project management field. The difficulty of making good predictions of the benefits of the use of coaching for project management in organizations and projects has been emphasized (Berg \& Karlsen, 2013, 2016). Moreover, the general reduction of training budgets has brought an increasing need to consider what key components lead to an effective coaching relationship and their impact on the projects' results.

Considering this research gap, we propose to contrast the following research hypotheses:

H1. Executive coaching is an effective means of improving the personal competencies of project managers.

H2. Executive coaching has differential impacts on the personal competencies of project managers.

\section{Methodology}

\section{Research Design and Sample}

The research was conducted by means of a quasi-experimental pretest-post-test study. The participants in the study were 


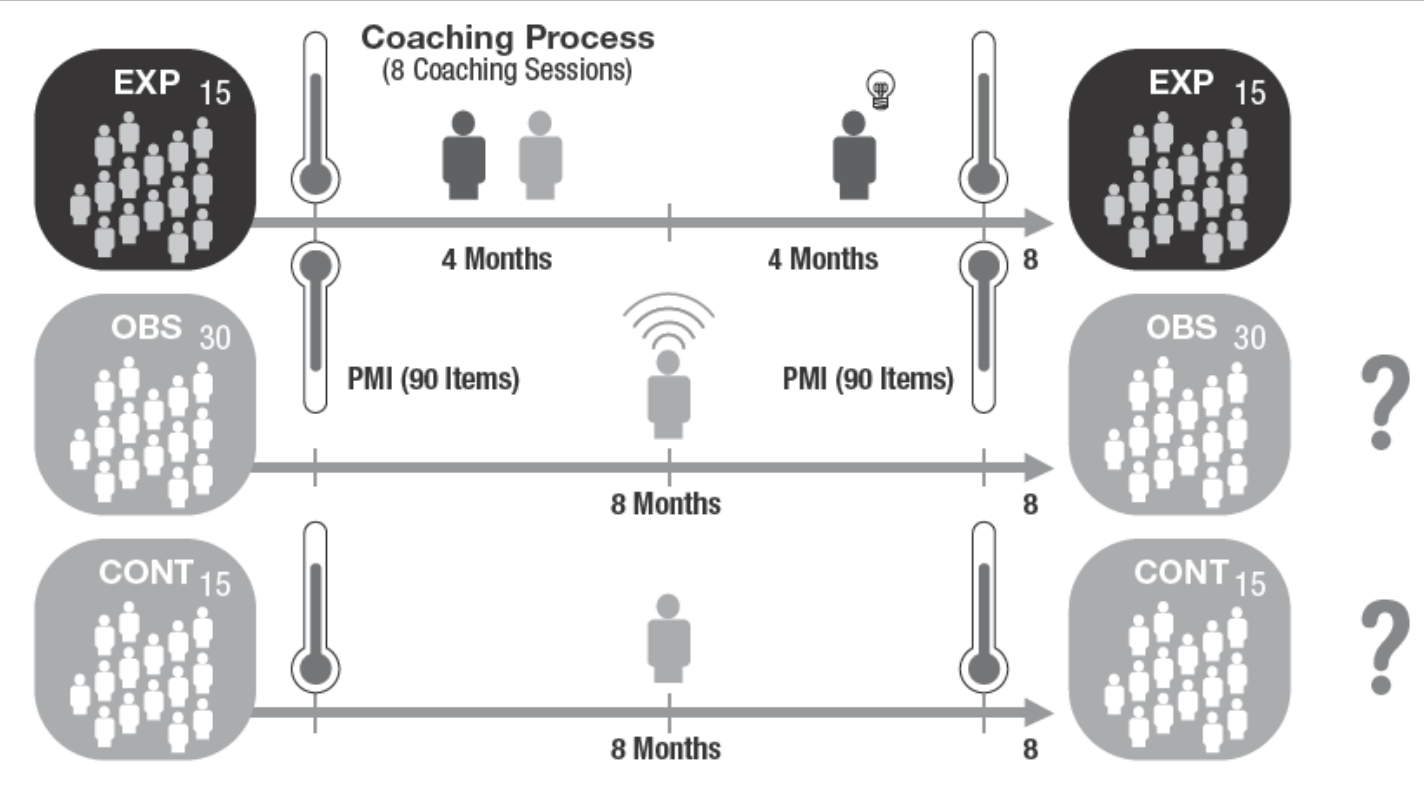

EXP: Project Managers (Experimental Group) OBS: Observers (Experimental Group) CONT: Project Managers (Control Group)

Figure I. Research design.

selected from a professional network on the basis of independence, representativeness, and heterogeneous principles that gave them the opportunity to voluntarily participate in the project.

The participants were divided into an experimental group and a control group based on their commitment and availability to participate until the end of the study, and controlling variables such as age, sex, education, experience, organizational sector, number of projects, and people led.

The experimental group consisted of active project managers $(n=15)$ and the observers $(n=30)$ working with them (two for each one), as supervisors and/or project team members, from 11 different Spanish organizations. The project managers were told to recruit the observers from their own organization and to select persons who worked relatively close to them, and whose performance was familiar to them in order to perceive changes easily. In some cases, an observer was a supervisor of the participants. In all cases, at least one observer was a member of the project team. The two-member observers provided their feedback individually and anonymously. To mitigate concerns about the use of the surveys and assessments bias, the nature of the research was explained to the observers, guaranteeing the anonymity and confidentiality of the results at an individual level.

The control group was composed of other project managers $(\mathrm{n}=15)$ independent from the previous managers and without direct contact or information from the experimental group. The control group did not receive any coaching intervention and participated voluntarily as well (Figure 1). The average participant in the experiment is 37 years old, has nine years of
Table 2. Sample Features: Organizational Sectors Participating in the Experiment

\begin{tabular}{lcc}
\hline & \multicolumn{2}{c}{ Sample } \\
\cline { 2 - 3 } & $\begin{array}{r}\text { Project Managers (Experimental } \\
\text { and Control Groups) }\end{array}$ \\
\cline { 2 - 3 } Organizational Sector & $\mathrm{N}$ & $\%$ \\
\hline Transport & 5 & $16.7 \%$ \\
Defense & 4 & $13.3 \%$ \\
International development & 4 & $13.3 \%$ \\
Education & 4 & $13.3 \%$ \\
Energy & 4 & $13.3 \%$ \\
Construction & 3 & $10.0 \%$ \\
Fashion & 2 & $6.7 \%$ \\
Agribusiness & $\mathrm{I}$ & $3.3 \%$ \\
Banking & $\mathrm{I}$ & $3.3 \%$ \\
Consulting services & $\mathrm{I}$ & $3.3 \%$ \\
Health & $\mathrm{I}$ & $3.3 \%$ \\
Total & 30 & $100 \%$ \\
\hline
\end{tabular}

management experience, and leads five projects with approximately 13 people. In addition, they hold an engineering degree and work in the engineering project field. Table 2 shows the specific organizational sectors where the project managers in the research worked.

Participants in the experimental group were engaged in coaching and were administered project management personal competency surveys based on the PMCD framework (PMI, 2007,2017 a) prior to the initiation of the coaching program. The project managers assessed themselves (self-perceptions), 
and the observers assessed the project managers' performance using the same survey in a $360^{\circ}$ feedback approach.

The control group participants, who were not involved in the coaching process, were given the same surveys as the experimental group participants. Similarity, in the level of personal competencies in both groups, was checked by comparing survey results prior to the initiation of the coaching program.

\section{The Executive Coaching Intervention}

An executive coaching intervention to be used in a project management context was needed so that a valid and standardized methodology could be used with all participants in the experiment. For that purpose, the intervention was designed with two levels of approach.

First, for each individual coaching session, the GROW (Goals, Reality, Options, Will) model (Landsberg, 2015) was applied. Although other models, such as the ACHIEVE (Assess current situation, Creative brainstorming, Hone goals, Initiate options generation, Evaluate options, Valid action program design, Encourage momentum) model (Dembkowski \& Eldridge, 2006) and the OUTCOMES (Objectives, Understand the reasons, Take stock of the present situation, Clarify the gap, Options generation, Motivate to action, Enthusiasm and encouragement, Support) model (Mackintosh, 2003), were considered, the GROW model was selected because of its relative simplicity and international recognition and use in the coaching field. During coaching sessions, various tools were used for the improvement of the personal competencies. These included SMART (Specific, Measurable, Agreed, Realistic, Time phased) objectives definition, performance criteria identification, project managers' mission and vision statements, and $360^{\circ}$ feedback or change of beliefs.

Next, a second-level approach was needed for the management of the entire coaching process. For that purpose, a systematic project management coaching process was designed and followed by the authors based on expert opinion, literature review, and previous coaching experiences. This served as a means to guarantee replicability, provide guidance to all stakeholders, allow coordination, and facilitate the use of a common vocabulary based on coaching and project management principles. This process is based on the following phases:

Contextualization (Phase 1): oriented to the adequate beginning of the process, including its approval, the establishment of agreement and bases, obtaining information, setting working principles, and generating trust with all the stakeholders.

Objective setting (Phase 2): focused on the definition and adequate planning of process objectives and aligning them to the interests of the project manager and the organization.

Development (Phase 3): focused on competency development, where attitudes, thinking, emotions, and behavior patterns are changed in a stable manner to achieve the objectives established in the previous phase. During the development phase, actions are carried out to achieve the objectives.
Empowering and closure (Phase 4): activities oriented to the empowerment of the project manager so that they have more self-leadership and are able to continue their own improvement autonomously. Likewise, this phase includes the closure and final assessment of the process.

The whole process consists of eight individual coaching sessions (of 90 minutes each) with the 15 project managers over a period of four months, which means a total of 120 coaching sessions. All the processes were headed by an ICFcertified professional coach in 2016 and 2017.

The project management coaching process defined (CODE process) consisted of the four clearly defined phases (Figure 2) as well as a set of principles, tools, and methods. The principles are based on (1) using executive coaching as a tool for the improvement of competencies, (2) understanding project management as a unique and challenging profession, (3) acknowledging the importance of the role responsible for guiding a project management coaching process (i.e., the project coach) to have the necessary competencies, and (4) considering the coaching process as a project to effectively manage it. The tools and methods are those from project management knowledge areas useful for managing the coaching process, such as planning and scope management, quality management, stakeholder management, and risk management.

\section{Measures}

Measures of six personal competency constructs (competency units) were used based on the PMCD framework performance criteria (PMI, 2007, 2017a). Thus, these six personal competency units are defined by a total of 90 performance criteria (items) as follows:

- Communicating (12 items): Effectively exchanges accurate, appropriate, and relevant information with stakeholders using suitable methods. Sample item: Actively listens.

- Leading (15 items): Guides, inspires, and motivates team members and other project stakeholders to manage and overcome issues to effectively achieve project objectives. Sample item: Expresses positive expectations of team.

- Managing (12 items): Effectively administers the project through the appropriate deployment and use of human, financial, material, intellectual, and intangible resources. Sample item: Ensures expectations and responsibilities are clear to team members and they understand their importance to the project.

- Cognitive ability (17 items): Applies an appropriate depth of perception, discernment, and judgment to effectively direct a project in a changing and evolving environment. Sample item: Understands project stakeholders' needs, interests, and influence for project success.

- Effectiveness (16 items): Produces desired results by using appropriate resources, tools and techniques in all 


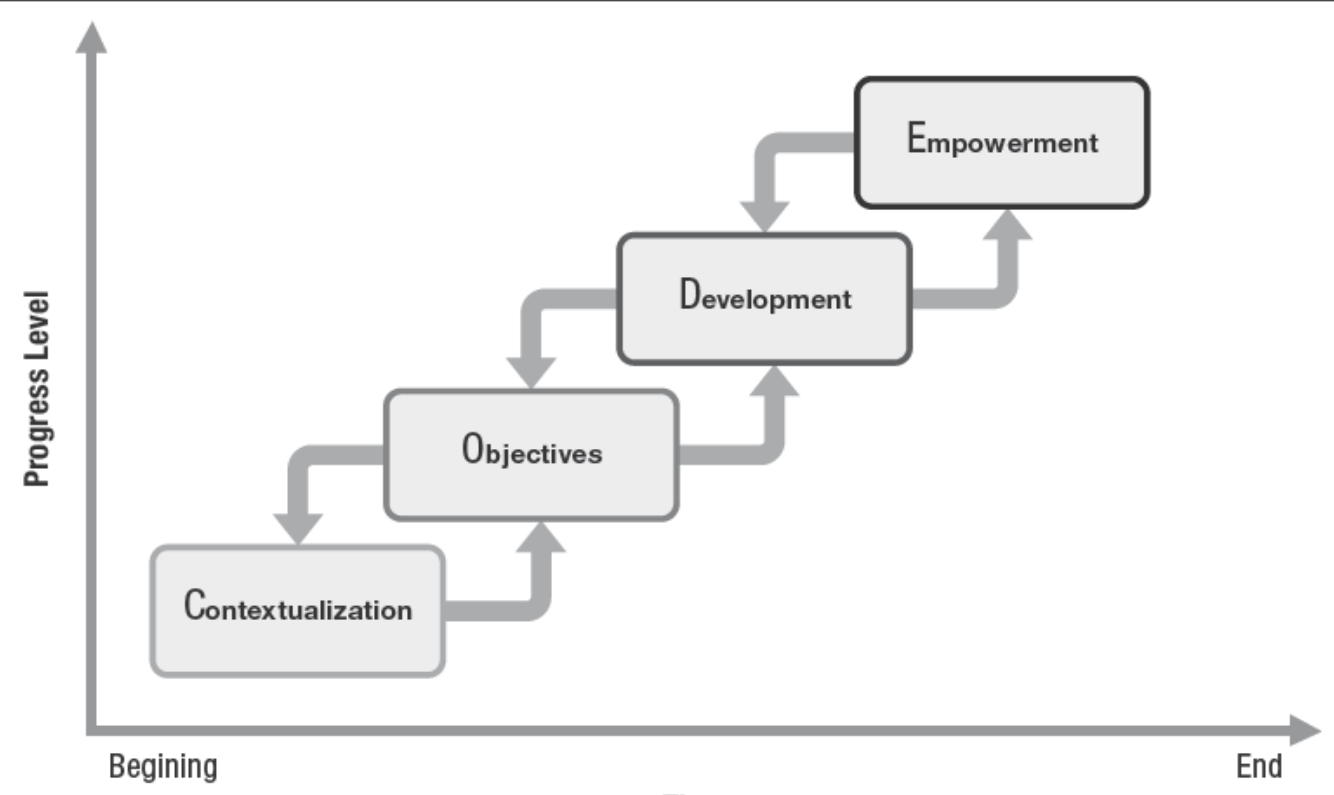

Time

Figure 2. CODE process phases.

project management activities. Sample item: Employs appropriate problem-solving techniques.

- Professionalism (18 items): Conforms to ethical behavior governed by responsibility, respect, fairness, and honesty in the practice of project management. Sample item: Maintains and respects confidentiality of sensitive information.

To measure the competencies, each item was defined by an extended Likert scale (from 1 to 7), which was used by all the participants in the research to assess the frequency of each behavior in the workplace.

Means and standard deviations for the performance criteria and competency units were calculated in order to assess the results and compare the impacts of coaching at different levels. An overall mean of personal competencies was also calculated with the same purpose.

\section{Data Analysis}

Data were collected at the individual level of analysis, which focused on the improvement of personal competencies before and after the coaching, over the eight-month period. Means and standard deviations of all the dependent variables were calculated before and after the experiment. Mean comparisons using a student's t-test for hypothesis contrasts were used so that the significance of competency improvements due to coaching could be determined.

To enrich the assessment of the impact of the coaching interventions, personal interviews following a semi-structural approach were conducted with each project manager from the experimental group after the intervention. This qualitative approach helps to provide the opportunity to gather information on a subjective basis and to describe reality from different and complementary perspectives. Individual interviews were conducted with all project managers and followed a list of themes and questions to cover. The interviews were conducted by the main author during 60 to 90 minutes with each project manager, based on a common guide and following an open-ended schedule of 13 questions subdivided into sections on the effectiveness of the coaching process, success factors, and impact on personal competencies. The semi-structured approach gave an opportunity to propose new topics and/or to change the order of questions depending on the flow of the conversation. All interviews were recorded and transcribed in order to prevent the loss of information, with the respondent's permission.

Finally, after the data had been gathered and results obtained, conclusions were drawn from a systemic view of the overall impact on performance at four different levels: project manager, project team, stakeholders, and organizational.

\section{Results}

\section{Personal Competency Improvements}

The main results of competency improvements, which were indicated by the quantitative approach, appear in Table 3. A visual representation of this results using spider charts is presented in Figures 3 through 5.

Project managers from the experimental and control groups had similar competency levels before the experiment with higher values for the professionalism and communicating competencies and lower values for managing and leading. This allows for the comparison of the results after the independent 


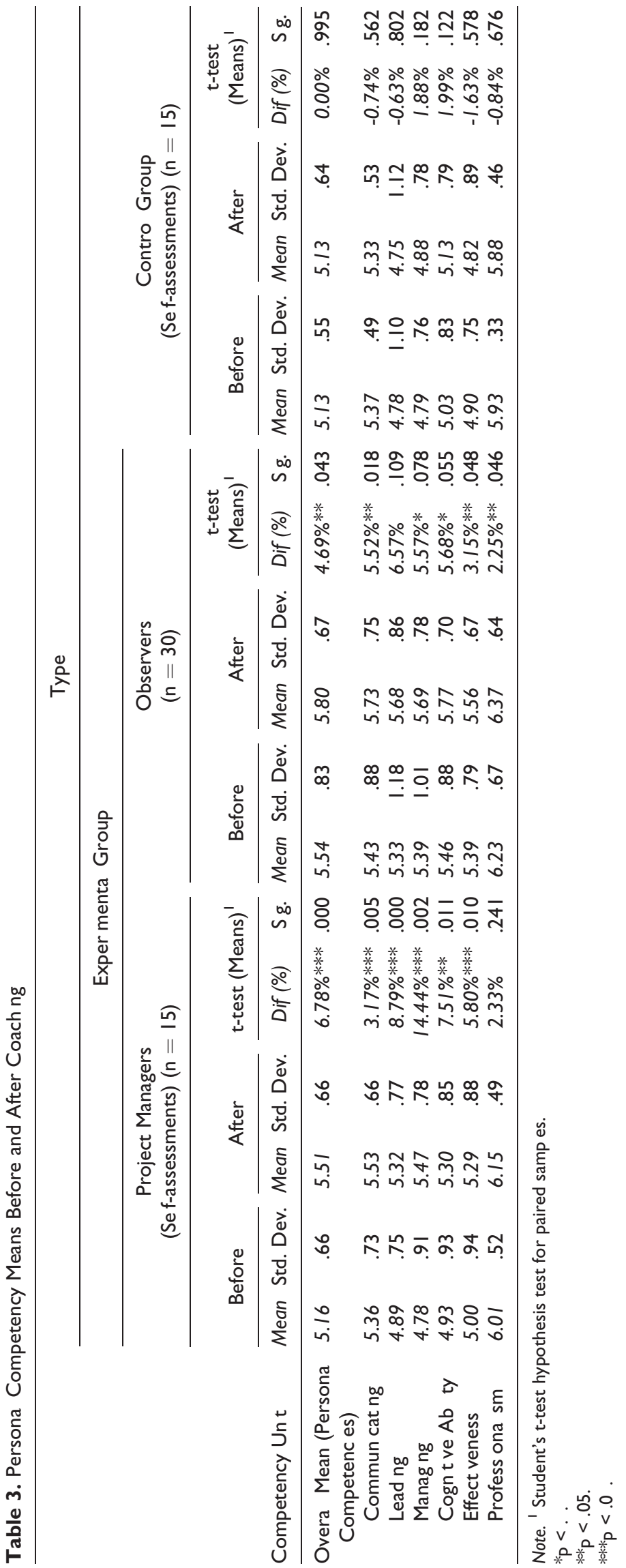




\section{Experimental Group: Project Managers}

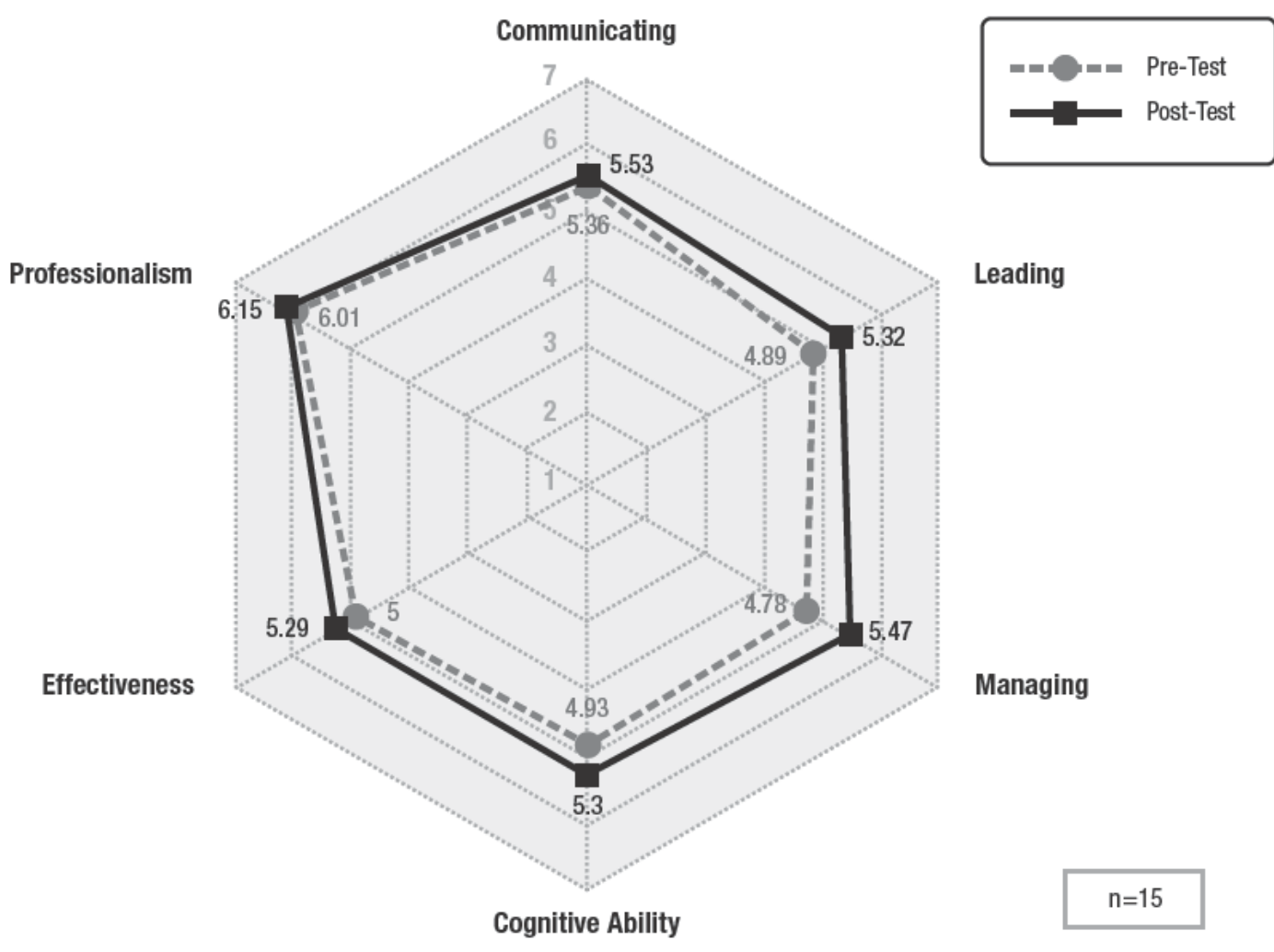

Figure 3. Project managers' pre test and post test personal competencies assessments.

variable manipulation, which is the application or not of project management coaching.

Before the experiment, the observers generally assessed the experimental group as scoring higher than the experimental group assessed themselves, although after a t-test comparison, it was determined that these differences were not statistically significant.

After the experiment, a significant improvement in the overall personal competencies mean of the experimental group was perceived, which was measured both through the self-assessments of the project managers (improvement of $6.78 \%$ ) and through the assessments of the observers (improvement of $4.69 \%$ ); there was no significant change by the control group.

The largest self-assessed improvements for the performance criteria were in the managing unit, with an average increase of $14.44 \%$, followed by the leading unit, with an improvement of $8.79 \%$. Observers indicated that there was a major improvement in leading, with $6.57 \%$, followed by cognitive ability, with $5.68 \%$.

Next, effectiveness and communication units showed significant self-assessed improvements of $5.80 \%$ and $3.17 \%$, respectively. For these competencies, observers also perceived significant showed improvements in effectiveness, with $3.15 \%$, and in communication, with $5.52 \%$.
The professionalism unit showed the smallest differences among the project managers of the experimental group ( $2.3 \%)$, but it must be taken into account that this competency started with very high initial values (above six out of seven).

In the control group, no changes in personal competencies were statistically significant using the t-test hypothesis test for paired samples (Sig. < 0.1). In general, the differences (although small and not significant) that were found in control group assessments could be explained by the completion of the survey at different times and the possibility of intervention by unanticipated variables (emotional state of the individual, project phase, period of the year, workload, etc.).

By focusing on the improvement of specific items (performance criteria) belonging to each competency unit, it was possible to identify those behaviors with higher levels of improvement based on both the experimental groups' selfassessments (project managers) and the observers' group assessments.

Table 4 shows the summary of the major findings for the performance criteria improvements. The results show a very high impact based on the self-assessments related to ensuring that expectations and responsibilities are clear to team members, consolidating opportunities, and including experts in meetings and discussions. High impacts were also detected for behaviors related to expressing positive expectations of the 


\section{Experimental Group: Observers}


Leading

Managing

$\mathrm{n}=30$

Figure 4. Observers' pre test and post test personal competencies assessments.

team, disseminating information effectively, and promoting team learning.

On the other hand, lower impacts were perceived based on both the assessments of the project managers and the observers regarding some performance criteria within the professionalism competency unit, such as maintaining the confidentiality of sensitive information, understanding and actively supporting the project's and organization's mission and goals, working within a recognized set of ethical standards, and adhering to all legal requirements. Additionally, no change was perceived for observing discrepancies, trends, and interrelationships in project data and making timely decisions based on facts while managing ambiguity, which belong to the cognitive ability and effectiveness competency units, respectively.

During the semi-structured interviews after the coaching processes, several project managers underlined the effectiveness of coaching for improving their approach to organizing work, managing time, decision making, assertiveness, flexibility and facing changes, creativity, and creating a good working and team climate. They also indicated that the coaching caused them to feel better, managing their emotional states. The coaching also added to a sense of satisfaction and well-being, not only in their professional fields but also in their personal lives. A general agreement was found among the project managers (12 of 15), who participated in the experiment and who underlined a high positive impact of coaching on their ability to find strategies for coping with stress and difficult situations, such as conflicts and crises.

On the other hand, the project managers stated that the coaching was not so effective in improving their professionalism, ethics, and commitment to the organization. This could be a topic of interest for further research.

Finally, in regard to the use of the project management coaching process (CODE process) for this research, almost all participants (13 of 15) agreed that this structured approach was useful in understanding the scope of the intervention and helped in achieving the objectives gradually and more effectively. The participants also specially emphasized the importance of the coach having appropriate skills and being able to generate an environment of trust, respect, honesty, and mutual commitment. In addition, the use of questions to raise awareness and the feedback that the coach offered during the sessions seem to have been greatly valued.

\section{Discussion}

H1 was supported. Based on both the quantitative and the qualitative approaches, executive coaching has been demonstrated to be effective for the strengthening of project managers' personal competencies. Coaching is presented as an 


\section{Control Group: Project Managers}

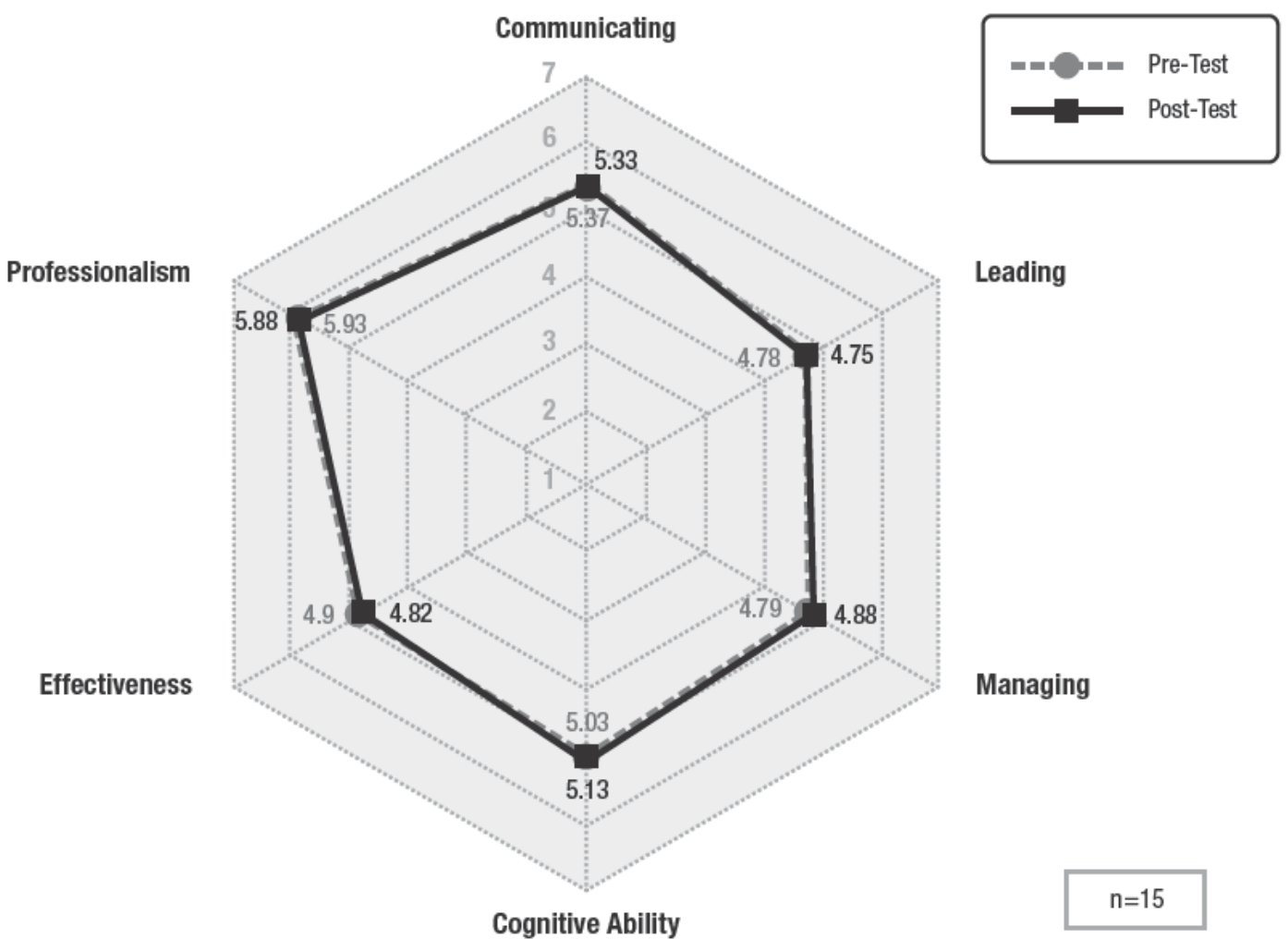

Figure 5. Control group's pre test and post test personal competencies assessments.

effective way to help project managers promote changes that result in a better professional performance.

The effects of coaching seem to be recognized both by the project managers themselves and by the people who interact with them in the organization (observers). Nevertheless, greater improvements have been found in the project managers' selfassessments than in the observers' assessments. This could be explained by two fundamental reasons. First, it is understood that observers may take longer to perceive the changes experienced by experimental subjects because they require time to consistently detect different behaviors and change their perception of the other person (in this case, they had only four months after the end of the process). Likewise, subjects who have lived the process may have a tendency to feel that the process has served to improve their skills and may have greater self-esteem, overestimating the results obtained. Notwithstanding, the contrast in the evaluations (self-assessments and observers' assessments), it is possible to guarantee that the changes experienced have been remarkable and significant, which gives the results a high robustness.

Although it is known that coaching can be a leadership style that requires time (Goleman, Boyatzis, \& McKee, 2002), its benefits under the right circumstances can be very remarkable. By generating appropriate project environments, the project would benefit from the flexibility and dynamism of systems where people feel increasingly empowered to deploy their own potential.

These results support previous findings in the literature review about the positive impact of executive coaching on work behaviors and attitudes (Grant et al., 2009; Hall et al., 1999; Jones et al., 2014; Olivero et al., 1997; Page \& de Haan, 2014; Smither et al., 2003), in this case, for project management functions. To fully understand the potential benefits of executive coaching, it is important to go a step further, and record evidence of specific improvements in different competencies.

$\mathrm{H} 2$ was supported. The coaching intervention has had different impacts on certain competencies than others. Particularly surprising are the self-assessed improvements in the managing unit, although improvements have also been seen in other performance criteria for other very notable units of competency, such as leading and cognitive ability. Executive coaching has a direct impact not only on leadership and emotional competencies, but also on management. This includes day-to-day attitudes toward managing project resources effectively. Coaching has been frequently related to the improvement of leadership competencies (Perkins, 2009; Rezania \& Lingham, 2009; Thach, 2002). This may be because it is considered to be a leadership style itself (Goleman et al., 2002). However, this research shows that the effectiveness of coaching improves 
other personal competencies, such as managing, cognitive ability, or communication. This implies a need to better understand the impact of coaching on performance and how it works, in line with Theeboom et al. (2014).

However, no significant difference was found in regard to the overall professionalism unit mean. This may be explained by the fact that the participants in the experiment had already achieved high performance in this competency area. Therefore, this research gives no evidence to support the fact that coaching could strengthen overall professionalism competencies. These include ethical behaviors governed by responsibility, respect, fairness, and honesty in the practice of project management. Thus, we consider it necessary to conduct further research to explore this topic further.

For specific performance criteria, major differences were found. Some specific observable behaviors improved up to $25 \%$, and others did not suffer any impact. The higher impacts of the coaching intervention were related to ensuring that expectations and responsibilities are clear, consolidating opportunities, and including experts to obtain stakeholder support.

The project managers participating in the experiment also underlined a high positive impact of coaching on their ability to cope with stress and difficult situations. This is in line with previous literature review (Berg \& Karlsen, 2013; Grant et al., 2009).

On the other hand, lower impacts of coaching from the performance criteria perspective were more related to professionalism with regard to maintaining confidentiality, supporting the project's and organization's missions, and working within a set of ethical standards and legal requirements. Lower impacts on the professionalism unit should be considered carefully, since the initial values for this unit justify a lower margin of improvement from the experimental intervention. Nevertheless, lesser changes were also perceived for observing project data and making timely decisions while managing ambiguity, which were not so high in the beginning. Since this study reveals various significant effects of executive coaching on several project managers' personal competencies, it implies the need for further review and analysis to determine the project and organizational contexts in which coaching could be more useful and, therefore, recommended.

In addition, further research should provide a better understanding of the main success factors of a coaching intervention in the project management field and how to guarantee its excellence. The first insights from the CODE process design and its result reveal that it is useful to define and employ certain phases and common principles during an executive coaching intervention, while paying special attention to ensure that the coach has the appropriate skills. Therefore, efforts to improve coaching results in the project management environment should focus on defining best practices, new models, coaching competencies, and standards, as Dippenaar and Schaap (2017) argue. In this case, the challenge in the application of defined standards and models arises from the need to adequately combine the structure or rigidity of models with the flexibility that is required when working with people, especially in contexts of change and learning skills.

Another issue to consider is the use of coaching skills by project managers with their team members. Since this facilitates the empowerment of the individual while attending to the specific needs of the project, it can be very useful in order to enhance certain styles of project leadership. By generating appropriate project environments, the project can benefit from the flexibility and dynamism of systems in which people feel increasingly empowered to exercise their potential.

\section{Limitations}

The research carried out is not exempt from limitations that have emerged throughout. In the first place, it is necessary for the generalization of the results to take into account the limitations associated with the characteristics of the sample. This study was based on the contributions of 15 experimental subjects, 30 observers, and 15 control subjects. Although the information extracted from each experimental subject has been extensive, a larger sample size would guarantee greater validity and reliability of the results obtained. Also, a more heterogeneous sample, for example, covering project managers from different regions or nationalities, could allow for the detection of additional aspects of interest. Some bias could have arisen during personal competencies assessments from expectations of improvements in the experimental group (both project managers and observers). Also, changes in self-assessments by control group members could have been affected by their knowledge that others were receiving coaching, but they were not.

On the other hand, it must be taken into account that only one coach participated in the exercise of the project management coaching processes. Although the consistency and homogeneity of the coaching intervention was warranted, we might wonder if some results could be conditioned by the coaching style itself or the personal characteristics and skills of the coach.

\section{Conclusions}

The need to assess different methods for the improvement of the personal competencies of project managers has led to the development of this research. In this case, executive coaching is evaluated in terms of effectiveness in improving the relevant personal competencies of project managers.

The results have shown the significant impact and effectiveness of coaching processes on five of the six relevant personal competencies proposed by the Project Management Institute. There was a higher impact on the PMI competency units for managing, leading, and cognitive ability. This was followed by significant improvements in communication and effectiveness. Overall, the professionalism competency unit did not show remarkable changes after the coaching intervention, which may 
be reasonable since the participants in the experiment had already achieved high levels of performance in this competency.

The project managers who participated in the experiment had a good opinion of the possibilities and effectiveness of coaching as a tool for changing and improving their attitudes and behaviors at work. They also claimed that following a structured approach based on well-defined phases and standards may have a positive impact on process effectiveness for an executive coaching intervention within an organization. This makes it important for the coach to possess the necessary skills.

The higher impacts perceived on performance after the application of coaching are given at different levels. At the level of the project manager, improvements can be identified in their experiencing greater self-control, better ability to cope with daily work and changing demands, improved ability to face challenges and stressful situations, and improved wellbeing and personal satisfaction. At the level of the project team, particular improvement was made in the areas of enhancing the attitude of the project managers toward the team, increasing project managers' expressions of positive expectations, their more effective dissemination of information, their enhanced promotion of team learning and development, and their improved ability to ensure that expectations and responsibilities are clear. At the level of stakeholders, the higher effects produced by coaching are manifested in a greater capacity to influence and obtain stakeholder support and to handle conflict and crisis situations that may arise between individuals or project stakeholders. At the organizational level, the greatest effect of coaching seems to be the improved ability to consolidate opportunities and pass them on to the organization.

The profiles of the project managers show that they normally are highly responsible and professional managers, but they experience difficulty in overcoming challenging circumstances. As a result of coaching, the project managers have had the opportunity to set performance objectives, become aware of their strengths and weaknesses, and create action plans to effectively improve by doing. Therefore, we conclude that coaching is highly beneficial for project managers who manage difficult, demanding, and changing project environments.

\section{Funding}

The author(s) received no financial support for the research, author ship, and/or publication of this article.

\section{References}

Adams, S., \& Anantatmula, V. (2010). Social and behavioral influ ences on team processes. Project Management Journal, 41(4), 8998.

Ahadzie, D. K., Proverbs, D. G., \& Olomolaiye, P. (2008). Towards developing competency based measures for construction project managers: Should contextual behaviours be distinguished from task behaviours? International Journal of Project Management, 26(6), 631645.
Ahsan, K., \& Ho, M. (2013). Recruiting project managers: A comparative analysis of competencies and recruitment signals from job advertisements. Project Management Journal, 44(5), 3654.

Association for Project Management. (2008). APM competence framework. Buckinghamshire, UK: Author.

Australian Institute for Project Management (AIPM). (2008). Profes sional competency standards for project management. Sydney, Australia: Author.

Azim, S., Gale, A., Lawlor Wright, T., Kirkham, R., Khan, A., \& Alam, M. (2010). The importance of soft skills in complex proj ects. International Journal of Managing Projects in Business, 3(3), 387401.

Ballesteros Sánchez, L. I., Ortiz Marcos, I., Rodríguez Rivero, R., \& Juan Ruiz, J. (2017). Project management training: An integrative approach for strengthening the soft skills of engineering students. International Journal of Engineering Education, 33(6(A)), 19121926.

Berg, M. E., \& Karlsen, J. T. (2007). Mental models in project man agement coaching. Engineering Management Journal, 19(3), 313.

Berg, M. E., \& Karlsen, J. T. (2013). Managing stress in projects using coaching leadership tools. Engineering Management Journal, 25(4), 5261.

Berg, M. E., \& Karlsen, J. T. (2016). A study of coaching leadership style practice in projects. Management Research Review, 39(9), 11221142.

Blake, R. R., \& Mouton, J. S. (1968). The managerial grid: Key orientations for achieving production through people. Houston, TX: GPC.

Bono, J. E., Purvanova, R. K., Towler, A. J., \& Peterson, D. B. (2009). A survey of executive coaching practices. Personnel Psychology, 62(2), 361404.

Boyatzis, R. E. (1982). The competent manager: A model for effective performance. New York, NY: John Wiley \& Sons.

Boyatzis, R. E. (2008). Competencies in the 21st century. Journal of Management Development, 27(1), 512.

Boyatzis, R. E. (2009). Competencies as a behavioral approach to emotional intelligence. Journal of Management Development, 28(9), 749770.

Boyatzis, R. E., \& Goleman, D. (1996). Emotional competency inven tory. Boston, MA: The Hay Group.

Bozer, G., Sarros, J. C., \& Santora, J. C. (2014). Academic back ground and credibility in executive coaching effectiveness. Per sonnel Review, 43(6), 881897.

Brière, S., Proulx, D., Flores, O. N., \& Laporte, M. (2015). Compe tencies of project managers in international NGOs: Perceptions of practitioners. International Journal of Project Management, 33(1), 116125.

Cheng, M. I., Dainty, A. R., \& Moore, D. R. (2005). What makes a good project manager? Human Resource Management Journal, 15(1), 2537.

Chipulu, M., Neoh, J. G., Ojiako, U. U., \& Williams, T. (2013). A multidimensional analysis of project manager competences. IEEE Transactions on Engineering Management, 60(3), 506517. 
Clarke, N. (2010a). Emotional intelligence and its relationship to transformational leadership and key project manager competences. Project Management Journal, 41(2), 520.

Clarke, N. (2010b). Projects are emotional: How project managers' emotional awareness can influence decisions and behaviours in projects. International Journal of Managing Projects in Business, 3(4), 604624.

Creasy, T., \& Anantatmula, V. S. (2013). From every direction How personality traits and dimensions of project managers can concep tually affect project success. Project Management Journal, 44(6), 3651 .

Dainty, A. R., Cheng, M. I., \& Moore, D. R. (2005). Competency based model for predicting construction project managers' perfor mance. Journal of Management in Engineering, 21(1), 29.

Dembkowski, S., \& Eldridge, F. (2006). Das achieve coaching model ${ }^{\circledR}$ Ein systematischer ansatz für größere wirksamkeit im executive coaching. Organisationsberatung, Supervision Coaching, 13(2), 165170.

De Meuse, K. P., Dai, G., \& Lee, R. J. (2009). Evaluating the effec tiveness of executive coaching: Beyond ROI? Coaching: An Inter national Journal of Theory, Research and Practice, 2(2), 117134.

Dippenaar, M., \& Schaap, P. (2017). The impact of coaching on the emotional and social intelligence competencies of leaders. South African Journal of Economic and Management Sciences, 20(1), 116.

Druskat, V., \& Druskat, P. (2006). Applying emotional intelligence in project working. In S. Pryke \& M. Smyth (Eds.), The management of complex projects: A relationship approach (pp. 78 96). Oxford, UK: Blackwell Publishing.

El Sabaa, S. (2001). The skills and career path of an effective project manager. International Journal of Project Management, 19(1), 17.

Frame, J. (2002). The new project management (2nd ed.). San Fran cisco, CA: Jossey Bass.

Geoghegan, L., \& Dulewicz, V. (2008). Do project managers' lead ership competencies contribute to project success? Project Man agement Journal, 39(4), 5867.

Goleman, D., Boyatzis, R. E., \& McKee, A. (2002). The new leaders: Transforming the art of leadership into the science of results. London, England: Little, Brown and Co.

Grant, A. M., Curtayne, L., \& Burton, G. (2009). Executive coaching enhances goal attainment, resilience and workplace well being: A randomised controlled study. The Journal of Positive Psychology, 4(5), 396407.

Gustavsson, T. K., \& Hallin, A. (2014). Rethinking dichotomization: A critical perspective on the use of "hard" and "soft" in project management research. International Journal of Project Manage ment, 32(4), 568577.

Hall, D. T., Otazo, K. L., \& Hollenbeck, G. P. (1999). Behind closed doors: What really happens in executive coaching. Organizational Dynamics, 27(3), 3953.

Honey, P. (1988). Face to face skills. Farnham, UK: Gower Publishing. International Project Management Association. (2015). Individual competence baseline for project, programme \& portfolio manage ment. Zurich, Switzerland: Author.
Jones, R. J., Woods, S. A., \& Guillaume, Y. (2014). A meta analysis of the effectiveness of executive coaching at improving work based performance and moderators of coaching effectiveness. Paper pre sented at the British Psychological Society Annual Division of Occupational Psychology Conference, Brighton, England.

Joo, B. K. B., Sushko, J. S., \& McLean, G. N. (2012). Multiple faces of coaching: Manager as coach, executive coaching, and formal mentoring. Organization Development Journal, 30(1), 19.

Katz, R. L. (1955). Skills of an effective administer. Business classic fifteen key concepts for managerial success. Harvard Business Review, 33(1), 3342.

Kerzner, H., \& Saladis, F. P. (2011). What executives need to know about project management (Vol. 2). Hoboken, NJ: John Wiley \& Sons.

Landsberg, M. (2015). The Tao of coaching: Boost your effectiveness at work by inspiring and developing those around you. New York, NY: Profile Books.

Liikamaa, K. (2015). Developing a project manager's competencies: A collective view of the most important competencies. Procedia Manufacturing, 3, 681687.

Mackintosh, A. (2003). The successful coaching manager. Leicester, UK: Troubador Publishing Ltd.

McGregor, D. M. (1967). The professional manager. New York, NY: McGraw Hill.

Meng, X., \& Boyd, P. (2017). The role of the project manager in relationship management. International Journal of Project Man agement, 35(5), 717728 .

Mesly, O. (2015). Exploratory findings on the influence of physical distance on six competencies in an international project. Interna tional Journal of Project Management, 33(7), 14251437.

Müller, R., \& Turner, J. R. (2007). Matching the project manager's leadership style to project type. International Journal of Project Management, 25(1), 2132.

Müller, R., \& Turner, J. R. (2010a). Attitudes and leadership compe tences for project success. Baltic Journal of Management, 5(3), 307329.

Müller, R., \& Turner, J. R. (2010b). Leadership competency profiles of successful project managers. International Journal of Project Management, 28(5), 437448.

Muzio, E., \& Fisher, D. (2009). Soft Skill Quantification (SSQ): Human performance vs. metric. Cost Engineering, 51(3), 2631 .

Obradovic, V., Jovanovic, P., Petrovic, D., Mihic, M., \& Mitrovic, Z. (2013). Project managers' emotional intelligence A ticket to suc cess. Procedia Social and Behavioral Sciences, 74, 274284.

Olivero, G., Bane, K. D., \& Kopelman, R. E. (1997). Executive coach ing as a transfer of training tool: Effects on productivity in a public agency. Public Personnel Management, 26(4), 461469.

Othman, A., Abdullah, H., \& Ahmad, J. (2009). The influence of work motivation on emotional intelligence and team effectiveness rela tionship. Vision: The Journal of Business Perspective, 13(4), 114.

Page, N., \& de Haan, E. (2014). Does executive coaching work?. Psychologist, 27(8), 582586.

Parry, S. B. (1996). Just what is a competency? (And why should you care?). Training, 35(6), 58. 
Patanakul, P., \& Milosevic, D. (2008). A competency model for effec tiveness in managing multiple projects. The Journal of High Tech nology Management Research, 18(2), 118131.

Perkins, R. D. (2009). How executive coaching can change leader behavior and improve meeting effectiveness: An exploratory study. Consulting Psychology Journal: Practice and Research, 61(4), 298.

Petter, S., \& Randolph, A. B. (2009). Developing soft skills to manage user expectations in IT projects: Knowledge reuse among IT proj ect managers. Project Management Journal, 40(4), 4559.

Project Management Institute. (2007). Project manager competency development framework Second edition. Newtown Square, PA: Author.

Project Management Institute. (2017a). Project manager competency development framework Third edition. Newtown Square, PA: Author.

Project Management Institute. (2017b). A guide to the project man agement body of knowledge (PMBOK ${ }^{\circledR}$ guide) Sixth edition. Newtown Square, PA: Author.

Rezania, D., \& Lingham, T. (2009). Coaching IT project teams: A design toolkit. International Journal of Managing Projects in Busi ness, 2(4), 577590.

Salovey, P., \& Mayer, J. D. (1990). Emotional intelligence. Imagina tion, Cognition and Personality, 9(3), 185211.

Sauser, B. J., Reilly, R. R., \& Shenhar, A. J. (2009). Why projects fail? How contingency theory can provide new insights A compara tive analysis of NASA's Mars climate orbiter loss. International Journal of Project Management, 27, 665679.

Shao, J. (2018). The moderating effect of program context on the relationship between program managers' leadership competences and program success. International Journal of Project Manage ment, 36(1), 108120.

Skulmoski, G. J., \& Hartman, F. T. (2010). Information systems proj ect manager soft competencies: A project phase investigation. Project Management Journal, 41(1), 6180.

Smither, J. W., London, M., Flautt, R., Vargas, Y., \& Kucine, I. (2003). Can working with an executive coach improve multisource feedback ratings over time? A quasi experimental field study. Per sonnel Psychology, 56(1), 2344.

Stevenson, D. H., \& Starkweather, J. A. (2010). PM critical compe tency index: IT execs prefer soft skills. International Journal of Project Management, 28(7), 663671.

Takey, S. M., \& de Carvalho, M. M. (2015). Competency mapping in project management: An action research study in an engineering company. International Journal of Project Management, 33(4), 784796.

Thach, E. C. (2002). The impact of executive coaching and $360^{\circ}$ feedback on leadership effectiveness. Leadership \& Organization Development Journal, 23(4), 205214.
Theeboom, T., Beersma, B., \& van Vianen, A. E. (2014). Does coach ing work? A meta analysis on the effects of coaching on individual level outcomes in an organizational context. The Journal of Pos itive Psychology, 9(1), 118.

Thornberry, N. E., \& Weintraub, J. R. (1983). The project manager: What it takes to be a good one. Project Management Quarterly, 14(1), 7376.

Zhang, F., Zuo, J., \& Zillante, G. (2013). Identification and evaluation of the key social competencies for Chinese construction project managers. International Journal of Project Management, 31(5), 748759 .

\section{Author Biographies}

Luis Ballesteros-Sánchez is an industrial engineer and $\mathrm{PhD}$ from the Universidad Politécnica de Madrid, and holds a master's degree in the psychology of human behavior. $\mathrm{He}$ is also Assistant Professor of Engineering Projects at this university. Ballesteros-Sánchez is an executive coach and a member of the Project Management and Quality Research Group. His research fields of interest are the development of project management personal competencies, such as leadership and communication that are applied to project success. He can be contacted at luisignacio.ballesteros@upm.es

Isabel Ortiz-Marcos is a mechanical engineer who holds a $\mathrm{PhD}$ in industrial engineering from the Universidad Politécnica de Madrid, where she is also Associate Professor of Engineering Projects and Project Management. OrtizMarcos is a certified Project Manager Professional (PMP) ${ }^{\circledR}$ by the Project Management Institute and an IPMA Level D. She is a member of the Project Management and Quality Research Group, and a member of the Organization, Quality and Environment Cooperation Group at the Universidad Politécnica de Madrid. Her current research fields of interest are competencies and professional skills applied to project management in multicultural contexts and international development projects and quality management. She can be contacted at isabel.ortiz@upm.es

Rocío Rodríguez-Rivero is an electrical engineer experienced in international engineering projects from the Universidad Politécnica de Madrid, where she is Assistant Professor of Engineering Projects and a member of the Project Management and Quality Research Group. Her research fields of interest are risk management in multicultural contexts and international development projects. She can be contacted at rocio.rodri guez@upm.es 